\title{
Two New Texts on Medicine and Natural Philosophy by Abū Bakr al-Rāzī
}

\author{
PETER E. PORMANN \\ MANCHESTER UNIVERSITY
}

and

\author{
EMILY SELOVE \\ UNIVERSITY OF EXETER
}

\begin{abstract}
This paper introduces two newly discovered epistles by the celebrated physician and philosopher Abū Bakr Muhammad ibn Zakariyyä’ al-Rāzī (Rhazes, d. ca. 925). The first epistle addresses the question of why and how clothing can be used both to stay warm and to stay cool, drawing on the Aristotelian tradition of problem literature (problémata physiká). The second epistle arises out of a court polemic and treats the question of whether one should consume mulberries after watermelons. This study offers analysis, editions, and translations of these previously unknown epistles, situating them within their broader literary and cultural contexts.
\end{abstract}

\section{INTRODUCTION}

It is not often that one discovers a new text by a well-known author. Here we present two texts that were thought to be lost, both by the great clinician and philosopher $\mathrm{Abu}$ Bakr Muhammad ibn Zakariyyầ al-Rāzī, celebrated not only for his innovative medical thinking, but also for his unconventional ideas about life and the universe, among other things. ${ }^{1}$ Al-Rāzì (Rhazes, d. ca. 925 C.E.) was among the most influential scholars in the history of medicine, and his works were often translated into Latin, especially his famous study of smallpox and measles. He was well acquainted with ancient Greek medicine and language, but did not slavishly follow the giants of the ancient Greek medical tradition, famously penning a work titled Shukūk 'alā Jälīnūs (Doubts about Galen). As much philosopher as physician, he favored empirical thought and scientific experimentation. In addition to teaching and running hospitals in Rayy and Baghdad, he participated in courtly and social gatherings of intellectuals. These sittings (majälis) can be seen in part as developments of the ancient Greek sympotic tradition and the broader Mediterranean tradition of learned debate or literary recitions in a semi-informal social setting. The competitive atmosphere of these learned social gatherings is strongly felt in the two recently discovered treatises discussed below.

These two texts deal with questions of natural history and dietetics respectively. They originated in the debate milieu of elite Abbasid society, where courtiers would engage in arguments in front of the caliph or other high-ranking officials. In the first epistle, the question under debate was why one sometimes undresses in order to cool off and at other times covers oneself to achieve the same result (for instance, in order to protect the body from the sun). The second epistle passionately defends the benefits of eating mulberries after watermelon.

We would like to thank the two anonymous JAOS reviewers for their helpful suggestions. The research was carried out as part of the project "Arabic Commentaries on Hippocratic Aphorisms," funded by the European Research Council.

1. H. Daiber, "Abū Bakr al-Rāzī," in Philosophie in der islamischen Welt, vol. 1: 8.-10. Jahrhundert, ed. U. Rudolph, Grundriss der Geschichte der Philosophie (Basel: Schwabe, 2012). 
Both epistles have hitherto only been known from the bio-bibliographical literature. ${ }^{2}$ The first is mentioned in Ibn al-Nadīm's Fihrist in the list of al-Rāzī's publications as Kitāb al-Ta'arri wa-l-tadaththur (Book on Getting Naked and Covering Oneself); ${ }^{3}$ in Ibn Abi Ușaybi'a as Fì l-'illati llatī yudfa'u harru l-hawä'i marratan bi-l-takashshufi wa-marratan bi-l-tadaththur (On the Reason Why Warmth Is Sometimes Dispelled by Uncovering Oneself and Sometimes by Covering Oneself $){ }^{4}$ and with nearly the same title in al-Bïrüni, which suggests that Ibn Abī Ușaybi ${ }^{\complement}$ a based his information about the title on al-Bīrūnī. ${ }^{5}$ The second epistle is recorded in Ibn al-Nadīm as al-Radd 'alā Jarì al-țabïb fimā khalafa fihi min amr al-tūt al-shāmī bi-'aqibi l-bitțikh (A Refutation of Jarī, the Physician, Regarding His Divergent Opinion about the Matter of [Eating] Mulberries after Watermelons); ${ }^{6}$ al-Bīrūni cites it as Fìmā jarā baynahū wa-bayna Jarīr al-tabib fì l-tūt 'aqiba l-bitțikh (On the Discussion between Him [sc. al-Rāzī] and Jarìr, the Physician, about [Eating] Mulberries after Watermelons) ${ }^{7}$ and Ibn Abī Ușaybi'a has an even more complete title: Maqālatun abāna

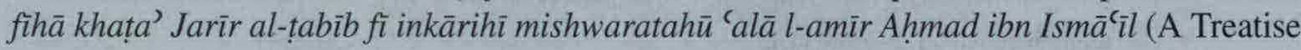
in Which He [sc. al-Rāzi] Demonstrates the Error of Jarir, the Physician, When He Invalidated His [sc. al-Rāzì's] Advice to Prince Ahmad ibn Ismāêil). ${ }^{8}$

We discovered these two texts in the course of gathering digital copies of all available manuscripts containing Arabic commentaries on the Hippocratic Aphorisms as part of our ERC-funded project at the University of Manchester. ${ }^{9}$ An entry in an eighteenth-century catalogue of medical manuscripts in Florence's historical Biblioteca Laurenziana first piqued our interest, as it lists Galen's commentary on Hippocrates's Aphorisms in Arabic translation as one of the items contained in MS orientali 413 (henceforth, MS L). ${ }^{10}$ As we subsequently discovered, however, this entry presents an unreliable account of the contents of MS L. The entry runs as follows:

\section{CCLX}

An Epistle, or "Golden Treatise," on medicine in Arabic. Its author's name appears as 'Alī, son of Moses, also called Imām al-Riḍā. He is considered the tenth of the twelve Imāms or priests of the Persian sect, who were the descendants of 'Alī, the son of Abū Tâalib and son-in-law of the false prophet [Muhammad]. He died in the city

2. F. Sezgin, Geschichte des arabischen Schrifttums (henceforth, GAS), 9 vols. (Leiden: E. J. Brill, 1967-84), 3: 292-93.

3. Ibn al-Nadīm, Kitāb al-Fihrist, ed. G. Flügel, 2 vols. (Leipzig: F. C. W. Vogel, 1871-72), 30.

4. Ibn Abī Ușaybi'a, 'Uyūn al-anbä' fì tabaqāt al-ațibbä'), ed. A. Müller (Königsberg, 1884), 1: 317; ed. 'A al-Najjār (Cairo: al-Hay’a al-Mișriyya al- 'Āmma li-l-Kitāb, 1996-2004), 3: 34. Müller's text needs to be emended, as already noted by J. Ruska, "Al-Bīrūnī als Quelle für das Leben und die Schriften al-Rāzī's," Isis 5 (1923): 26-50, at $38 \mathrm{n}$. 1. A new multi-scholar edition and translation of 'Uyūn al-anbä' is being prepared by a team led by $\mathrm{E}$. Savage Smith and S. Swain.

5. Epistle 51: Fì l-'illati llati [lahä] yudfa'u al-harru marratan bi-t-takashshufi wa-marratan bi-t-tadaththuri, in Fihrist-i kitābhā-yi Rāzì va nämhā-yi kitābhā-yi Bīrūni [...], ed. M. Muhaqqiq (Tehran: Dānishgāh-i Tiihrān, 1366 [1987]), 8.

6. Ibn al-Nadìm, Fihrist, ed. Flügel, 300.

7. Epistle 37, in Fihrist-i kitābhä-yi Rāzì, ed. Muhaqqiq, 7.

8. Ibn Abī Ușaybíca, 'Uyūn al-anb $\vec{a}$ ', ed. Müller, 1: 317; ed. al-Najjār, 3: 35.

9. See P. E. Pormann and K. I. Karimullah, "The Arabic Commentaries on the Hippocratic Aphorisms: Introduction," Oriens 45.1-2 (2017): 1-52.

10. S. E. Assemani, Bibliothecae mediceae Laurentianae et Palatinae codicum mss, orientalium Catalogus, (Florence: ex Typographio Albiziano, 1742-43), 375. 
of Țūs because he ate too many grapes, as appears from the Arabic Chronicle by Bar Hebraeus, part nine, passing away in the month of Șafar, in the year $203 h$ (818). ${ }^{11}$

- Also some short works on individual diseases and simple drugs, excerpted by an anonymous author from $a l-H \bar{a} w \bar{w}$, the work by Abū Bakr [in text, Au-Bacri] Muhammad son of Zakariyyā' al-Rāzī, also called the "Comprehensive [Book]."

- Galen's Commentary on Hippocrates's Aphorisms, translated from Greek into Syriac by Hunayn son of Ishāa, and-as one reads here-very accurately from Syriac into Arabic by Qusțā son of Lūqā (d. 300/912), of Baalbek, an eminent Christian philosopher.

- Excerpts from the "Canon of Medicine" [al-Qānūn fí l-țibb] by Ibn Sīnā, on diseases, and their causes and symptoms, written by a more recent hand.

- An octavo manuscript on oriental paper, consisting of 89 folios, written in Arabic letters and unpolished language by various hands. ${ }^{12}$

The catalogue is correct in its characterization of the contents of MS L as "unpolished" (rudis) at least in appearance. It is to this rough appearance that we must attribute the cataloguer's mistaken claim that the Hippocratic Aphorisms can be found within its pages. We found no trace of these aphorisms or their commentaries in MS L itself, but only the word fușül (aphorisms) in the well-nigh illegible table of contents. As described below, however, here this word does not refer to the Hippocratic Aphorisms but to the chapters (fusül) excerpted from Ibn Sīnā's (Avicenna, d. 1037) al-Qānūn fì l-țibb.

Though disappointed in our search for texts Hippocratical, we found instead these two previously unpublished treatises - not found, as the catalogue wrongly suggests, in al-Rāzī's influential work al-Hāwi fi l-tibb. The inaccuracy of the catalogue entry suggests the inadequacy of the catalogue itself and the possible existence of more unknown gems hidden in the Biblioteca Laurenziana collection of Arabic manuscripts.

\section{THE MANUSCRIPT}

MS L is listed in the catalogue as manuscript number 260, the number that also appears on its spine, despite being labeled as 259 on fol. 1a. As described, it is a codex with eightynine folios. It is small and portable, measuring about $12.5 \mathrm{~cm}$ by $15 \mathrm{~cm}$, bound in pale yellow vellum in thirteen quires. It is slightly waterstained and tattered, but in good condition. The paper is thick with visible pulp and has straight, tightly spaced laid lines. The margins are about $1.5 \mathrm{~cm}$ wide, and would have been wider before the pages were cut down for binding. The main text begins in mid-sentence on fol. 3a, containing a total of eight short works interspersed with poetry and very brief writings of a medical or religious nature.

The main hand (henceforth, hand one), namely, that of the scribe who wrote the eight principal works in this collection, is in black ink; it is unreliable and difficult to read. A second hand (henceforth, hand two) scribbled brief treatises and poems on spare pages that were left between the eight principal works. Its ink now appears faded and brown, and these scribblings, apparently religious and medical in nature, are also extremely difficult to read.

11. Gregory Bar Hebraeus, Catholicos of the Syriac Orthodox Church in the thirteenth century, mentions al-Riḍã in his Ta'rikh mukhtașar al-duwal, which was partially edited by E. Pococke (d. 1691). In Pococke's translation (Historia compendiosa dynastiarum, 2 vols. [Oxford, 1663], 1: 158): "In the year 203, 'Alī ibn Mūsā al-Riḍā̄) died; the cause of his death was eating grapes: when he had eaten a large amount, he suddenly died, on the last day of the month Șafar, in the city of Țūṣ."

12. Assemani, Bibliothecae mediceae Laurentianae, 375. 
Some of hand two's poems are colloquial in tone; for example, the interrogative aysh ${ }^{13}$ is used several times on fol. 67b, which contains a love poem, perhaps mystical in nature. Hand two, seemingly that of an enthusiastic if not entirely competent former owner of MS L, is also apparently responsible for inserting dots into the treatises copied by hand one, and these dots are especially unreliable. Certain words marking new sections are traced in rubrics, and in the final treatise of this work-selections from the Qānün (on which, see more below) the subject headings themselves, such as "coldness of the womb" (bard al-rahim) and "pains of the womb" (awjä al-rahim) on folio 74b, are written in rubrics. Each treatise ends with a colophon including a prayer for Prophet Muhammad and his family, the name of hand one, Yahyā 'Alī ibn al-Hājib, and the date of completion (during the month of Ramaḍān, 538h, corresponding to March 1144).

MS L includes a somewhat random and sensational gathering of topics, from poisons to sex, as described by very famous physicians. The hastily written and unreliable script on high-quality paper gives the overall impression that MS L was more of a novelty item than an aid to serious students of medicine, although we can only speculate about its exact purpose. On fol. 1a we find some medical poetry and library stamps of the Biblioteca Laurenziana. Fol. $1 \mathrm{~b}$ contains a short treatise that is apparently fragmentary and difficult to read. This seemingly polemical text, and at least some of the writing on fol. 1a, are written in hand two.

On fol. $2 \mathrm{a}$ are a number of recipes that appear to have been written by hand one. One recipe reads:

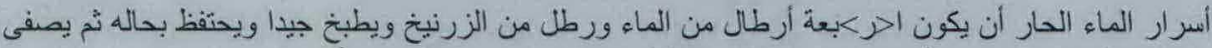

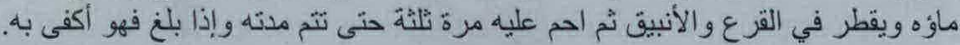

The secret to making hot water is to take four ritls of water and one ritl of arsenic. Cook it well and then leave it. Filter the liquid and dribble it into a curcubit and ambix. Then heat it for a third time, until the [necessary] time [for this] has passed. When it is finished, then it is complete.

\section{Content of the manuscript}

There is a table of contents on fol. $2 b$, probably in hand two. It reads: ${ }^{14}$

$$
\begin{aligned}
& \text { فا في هذه المجموعة } \\
& \text { [1] [الرسالة الذهبية للارضا عليه السلم إلى المأمون }
\end{aligned}
$$

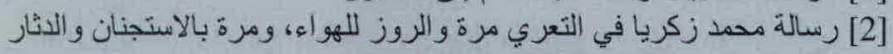

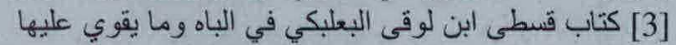

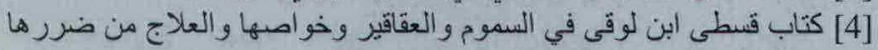

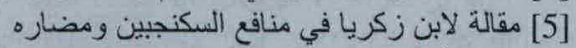

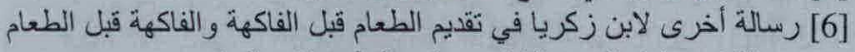

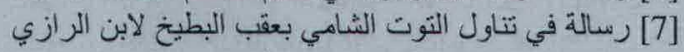

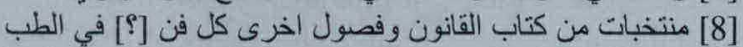

Table of contents

1. The Golden Epistle of al-Riḍā, peace upon him, to al-Ma'mūn. ${ }^{15}$

13. See A. Fischer, "Arab. ايش ," Zeitschrift der deutschen Morgenländischen Gesellschaft 59 (1905): 807-18; J. Blau, Grammar of Christian Arabic, Based Mainly on South-Palestinian Texts from the First Millennium (Louvain: Secrétariat du CSCO, 1966-67), 139-41.

14. The Arabic numbers in square brackets are added here for ease of reference.

15. See the edition and study by M. 'A. al-Bārr, al-Imām 'Alĩ al-Ridāa wa-risälatuhū fi l-tíbb al-nabawĩ: al-Risāla al-dhahabiyya. Awwal risāla fi l-tịbb al-nabawì (Beirut: Dār al-Manāhil, 1992). 
2. An epistle of Muhammad Zakariyyä’ [al-Rāzī] on sometimes nudity and seeking out the air [sic], and sometimes by wrapping and covering up. ${ }^{16}$

3. A work by Qusțā ibn Lūqā al-Ba'lbaki on sex and that which gives one the strength to do it. ${ }^{17}$

4. A work by Qusțā ibn Lūqā al-Ba'lbakī on poisons and drugs, their specific properties (khawäșs ) and remedies for their harms. ${ }^{18}$

5. A treatise by Ibn Zakariyya $\vec{a}$ on the uses and dangers of oxymel. ${ }^{19}$

6. Another epistle by Ibn Zakariyya $\vec{a}$ on presenting food before fruit and fruit before food. ${ }^{20}$

7. An epistle on eating Syrian mulberries after watermelon by Ibn Zakariyya $\vec{a} \cdot{ }^{21}$

8. Selections from the $Q \bar{a} n \bar{u} n$ and other chapters $(f u s \bar{u} l)^{22}$ [from] each section ${ }^{23}$ on medicine.

These titles loosely match the subjects of the epistles that follow in the following folios, the description sometimes expanding on the original titles (as in the first example, which tells how the Risāla dhahabiyya earned its name), and sometimes abbreviating the original title, as in the last, an excerpt of Ibn Sinā's Qānün:

$$
\begin{aligned}
& \text { [1] الرسالة من إلى [sic] الحسن الرضا عليه السلم إلى المأمون وقر أها فرح بها فرهاً عظيماً وأمر أن بكثب }
\end{aligned}
$$

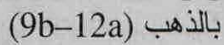

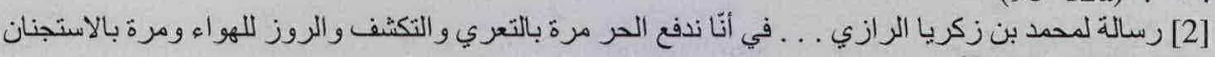

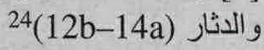

$$
\begin{aligned}
& \text { [3] كتاب قسطى ابن لوقى البعلبكي في الباه وما يقوي عليها و هو أحد و وعشرون باباً (15b-27a) }
\end{aligned}
$$

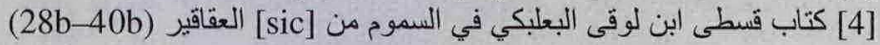

16. This is the first of the two texts edited below.

17. This epistle appears to be an earlier version of the text edited by N. A. Barhoum in "Das Buch über die Geschlechtlichkeit (Kitāb fî l-bāh) von Qustā Ibn Lūqā: Edition und Übertragung des arabischen Textes nach der Handschrift Nr. 242 der Universitätsbibliothek Istanbul" (diss., Erlangen-Nürnberg Univ., 1974), not to be confused with Qustā ibn Lūqā's other manual on sex (ed. G. Haydar, "Kitāb fill-bāh wa-mā yuhtāgu ilaihi min tadbïr albadan fi sti mälihi des Qustā Ibn Lūqā, 1. Abhandlung [Das Buch über die Kohabitation und die für ihre Ausübung notwendigen körperlichen Voraussetzungen]: Edition, Übertragung und Bearbeitung des arabischen Textes auf der Grundlage der Handschrift der Universitätsbibliothek Istanbul Nr. 243”' [diss., Erlangen-Nürnberg Univ., 1973]).

18. M. Ullmann, Die Medizin im Islam (Leiden: E. J. Brill, 1970), 327; M. Levey, ed., The Book on Poisons of Ibn Wahshìya and Its Relation to Early Indian and Greek Texts (Philadelphia, 1966); G. Gabrieli, "Nota biobibliografica su Qusțā Ibn Lũqāa," in Rendiconti della Reale Accademia dei Lincei, Classe di scienze morali, storiche e filologiche, ser. 5, vol. 21 (Rome, 1912), 346; Ibn al-Nadim, al-Fihrist, ed. Flügel, 317; Sezgin, GAS, 3: 273; P. Sbath, Al-Fihris (Catalogue de manuscrits arabes), 3 vols. (Cairo: Al-Chark, 1938-40; repr. Piscataway: Gorgias Press, 2012), 1: 59 no. 469, with reference to a manuscript copy in Aleppo. For the technical term khawäss, see Maimonides, On Poisons and the Protection against Lethal Drugs, ed. and tr. G. Bos (Provo: Brigham Young Univ. Press, 2009), 302 n. 27.

19. Oxymel (sikanjubin) is a mixture of honey and vinegar, boiled to syrup substance and used to cool the body down. For the treatise, see Ullmann, Medizin, 200; M. Najmābādī, Mu'allafāt va musannafāt-i Abū Bakr Muhammad ibn Zakariyyā-yi Rāzì: Hakìm va tabīb-i buzurg-i İrānī (Tehran: Dānishgāh-i Tihrān, 1339/1960), 96-97; Sezgin, GAS, 3: 288; Fihrist-i kitābhā-yi Rāzĭ, ed. Muhaqqiq, entry 32; J. Ruska, Tabula smaragdina: Ein Beitrag zur Geschichte der hermetischen Literatur (Heidelberg: C. Winter's Universitätsbuchhandlung, 1926), 36.

20. Ullmann, Medizin, 200; H. Ritter and R. Walzer, Arabische Übersetzungen griechischer Ärzte in Stambuler Bibliotheken, Sitzungsberichten der Preussischen Akademie der Wissenschaften, Phil.-Hist. Klasse, 1934, vol. 26 (Berlin: Verlag der Akademie der Wissenschaften, 1934), 834; Sezgin, GAS, 3: 287; Ruska, Tabula smaragdina, 36.

21. This is the second text edited and translated below.

22. The term fusül denotes both "chapters" and "aphorisms" (as well as seasons and differentia); in Ibn Sinā's Qänün fi l-țibb it is an organizational unit of division.

23. The reading kull fann is tentative; it does not fit into the syntax of the title. It could refer to the different sections (sing. fann) contained in Ibn Sīnā's Qānūn.

24. In MS L the title simply appears as Risāla li-Muhammad ibn Zakariyyā al-Räzī; we reconstructed the rest of the title from the opening paragraph of the epistle. 


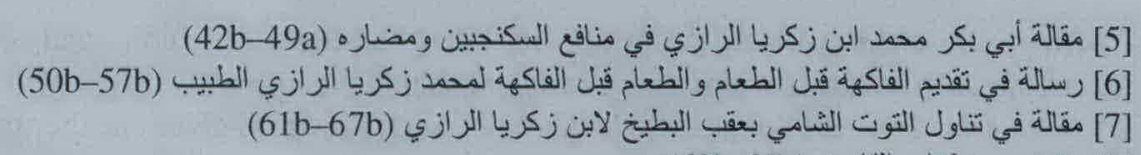

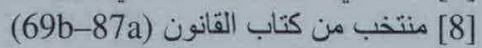

1. An epistle from to [sic] al-Hasan al-Riḍā (peace upon him) to al-Ma'mūn, and he read it and was pleased with it greatly and ordered that it be written in gold.

2. An epistle of Muhammad ibn Zakariyyā’ al-Rāzī . . . on the fact that we expel heat sometimes by nudity and undressing and seeking the air, and sometimes by wrapping and covering up.

3. A book of Qustāa ibn Lūqã al-Ba'lbakĩ on sex and what invigorates it, in twenty-one chapters.

4. A book of Qusțā ibn Lūqā al-Ba'lbakī on the poisons from drugs.

5. A treatise of Abū Bakr Muhammad ibn Zakariyyä’ al-Rāzĩ on the uses and dangers of oxymel.

6. An epistle on taking fruit before food and food before fruit by Muhammad Zakariyyä al-Rāzī, the physician.

7. A treatise on taking mulberries before watermelon by Ibn Zakariyyầ al-Rāzī.

8. Selections from the Qānūn.

As should be clear from these sample transcriptions, MS L contains problematic readings; since most of the texts cited have been edited, it is valuable chiefly as a source of otherwise unavailable material, such as the two texts presented in this article. Many of the religio-medical poems scribbled by hand two in between the treatises may also be unique. Qusțā ibn Lūqā's treatise on sex is given a fuller title than in any other available source, which shortens it to Kitāb al-Bāh, but a cursory comparison of the treatise with that provided in Barhoum's dissertation (see $\mathrm{n} .17$ above) shows that MS L contains many errors and misleading slips of the pen.

Thus, when editing the two texts presented below, we often had to contend with a very corrupt text that at first glance hardly made any sense. Through painstaking philological work we were able to reconstruct much of these two texts, but undoubtedly there are places where further conjecture is needed in order to overcome the poor quality of hand one and the misleading diacritical marks provided by hand two.

\section{TEXT 1: "ON EXPELLING HEAT"}

Al-Rāzi describes the topic of this treatise, which therefore could be the title, in the opening paragraph $(\S 1)$ as "What is the cause for the fact that we sometimes expel heat by getting naked, taking off clothes, and seeking to be in the air, while sometimes we do this by covering ourselves and enveloping ourselves"; for convenience's sake we shortened the title to "On Expelling Heat." Thus, al-Rāzī aims at explaining an apparent contradiction, namely, that wrapping oneself in clothes can be a means of becoming cooler rather than hotter. The addressee remains anonymous, and we can only infer that he must have frequented the same milieu as al-Rāzì, since al-Rāzì states that the addressee heard his answer to this question "that we debated" (allatī dārat baynanā). This debate took place during a majlis (a term to be discussed further below) ( $\$ 2.1$ ). Al-Rāzĩ describes his epistle as a summary (jumla, jawāmi $i^{`}$ of a longer public discussion with the addressee $(\$ 2.1-3)$.

The apparent paradox of expelling heat by covering oneself can be explained with reference to the ambient air $(\$ 3.1)$. If the air is cooler than the body, then it cools the body $(\$ 3.2)$. For this reason, we use fanning to cool ourselves $(\$ 3.4-6)$. If the air is warmer, however, then it warms the body and we need to protect ourselves from it in order to cool down, as when we cover ourselves with hats and light fabric for protection from the summer 
sun (§3.7-11). Al-Rāzī introduces the knowledge that air also reaches the heart and that its temperature has an effect on whether or not it is "refreshing," that is to say, whether it has the ability to cool the blood and produce pneuma. Al-Rāzi then tackles the main question of why this is so ( $\$ 4)$. Simply put, when air that is warmer than the body's surface comes into contact with it, it warms the surface, but at the same time is cooled itself. Therefore, if there is a steady flow of hot air, and fresh hot air replaces the old hot air that has cooled down, the warming effect is stronger ( $\$ 4.1-3)$. Al-Rāzi nuances the effect of hot air on the human being in order to refute the addressee, who holds that air warmer than the body's surface is deadly $(\$ 4.4)$. Only if the ambient air is warmer than the air in the heart is exposure to it lethal. If, however, it is warmer than the body's surface but cooler than the air in the heart, it still has a cooling effect, and does not lead to imminent death ( $\$ 4.5)$. It only damages the air in the pores (or passageways, masāmm) of the body; but this is not life-threatening in the short term ( $\$ 4.6-8)$. This air could corrupt the mixture of the heart if it lasted for a long period of time, but it does not: the hot air of the midday sun only lasts a few hours, and then cools down in the evening and at night $(\$ 4.9-11)$. Therefore, one is safe from death in most cases, even if damage ensues ( $\$ 4.12$ ).

At the end of the epistle, al-Rāzi explains that he will not deal with the topic of why one needs pneuma, since it would take too long and the ancients have already done so ( $\$ 5.1-2)$. Nor is it necessary to explain why one sometimes undresses to get warm (e.g., in a hot bath or by a fire), as the same principles of heat transfer apply ( $\$ 5.3-4)$. He concludes the epistle with a pious formula.

How the question is posed at the beginning of the epistle - "what is the cause for ...?" ( $m \bar{a} l$ - -illatu $f i$ )-shows that it belongs to the genre of question-and-answer or problem literature. ${ }^{25}$ The most famous classical Greek example is the Aristotelian Problémata physika, which deals with a wide variety of questions or problems in the field of natural history. ${ }^{26}$ Our specific question is not debated there, but one problem has some bearing on our text, namely, Problem ii. 9, which runs as follows:

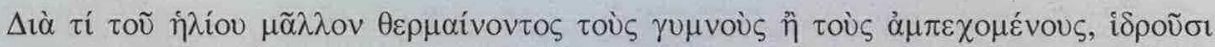

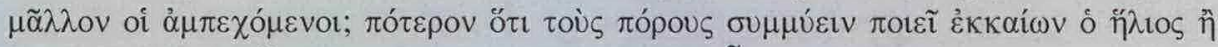

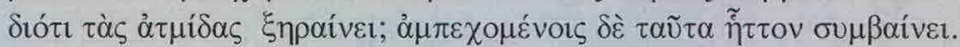

Why is it that although the sun warms naked people more than clothed ones, clothed people sweat more? Either because the sun closes the pathways (poroi) [sc. of the body] or because it dries the vapors. This happens less to clothed people. ${ }^{27}$

The Aristotelian Problemata were translated into Arabic, at least partly, by Hunayn ibn Ishạa or members of his circle. Al-Rāzī was acquainted with this translation, which he quoted extensively in al-Hāwi fi $l$-tibb. ${ }^{28}$ Problem ii. 9 runs as follows in its Arabic guise: ${ }^{29}$

25. For which, see H. Daiber, "Masā’il wa-Adjwiba," Encyclopaedia of Islam, 2nd ed., 12 vols. (Leiden: Brill, 1960-2004), s.v.

26. See now The Aristotelian Problemata physica: Philosophical and Scientific Investigations, ed. P. Mayhew (Leiden: Brill, 2015). For the transmission of the Aristotelian Problemata into Arabic, see L. S. Filius, "The Genre Problemata in Arabic: Its Motions and Changes," in Aristotle's Problemata in Different Times and Tongues, ed. P. De Leemans and M. Goyens (Leuven: Leuven Univ. Press, 2006), 33-54; idem, The Problemata Physica Attributed to Aristotle: The Arabic Version of Hunain ibn Ishāq and the Hebrew Version of Moses ibn Tibbon (Leiden: Brill, 1999).

27. 867a18-22 Bekker (trans. Pormann); for an alternate translation, see The Works of Aristotle Translated into English, tr. E. S. Forster, ed. W. D. Ross, vol. 7 (Oxford: Clarendon Press, 1927), Bk. II, sec. 9, p. 867a.

28. Filius, Problemata Physica Atributed to Aristotle, 43-44, cites numerous examples of Aristotelian natural problems translated into Arabic

29. Ibid., 134-35. 


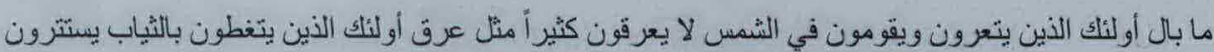

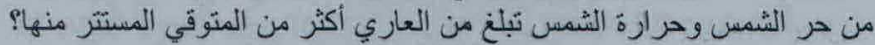

Why do those who are naked and stand in the sun not sweat a lot, as do those who cover themselves with clothes and shield themselves from the heat of the sun, while the heat of the sun reaches the naked more than [it does] someone who protects and shields himself from it?

Although this and the surrounding problems mainly deal with perspiration, there are two elements here that recur in al-Rāzì's epistle: the notion that the sun warms naked people more than clothed ones; and the idea of the pathways of the body being affected by an outside heat source. Galen was also well aware that long walks in the sun caused more damage to naked people than clothed ones, ${ }^{30}$ and al-Rāzī, who was familiar with Galen's text in which this quotation appears, might therefore have been influenced by it. ${ }^{31}$

Another Aristotelian problem, iii. 36, resembles part of al-Rāzì's discussion in his epistle more closely. Here the author asks,

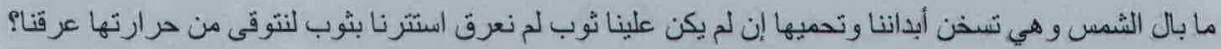
Given that the sun heats and warms our body, why is it that we do not sweat when we do not wear any clothes, yet when we shield ourselves with clothes in order to protect ourselves from the sun's heat, we do sweat?

And,

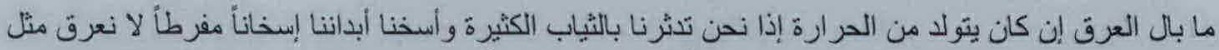

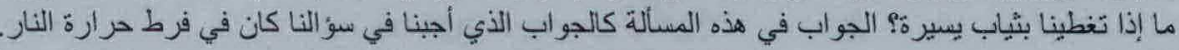
Given that sweat is generated by heat, why is it that when we wrap ourselves in a lot of clothes and heat our bodies excessively, we do not sweat to the same extent as when we cover ourselves with little clothes? The answer is similar to that which we give about the question about the excessive heat of fire. ${ }^{32}$

\section{Edition}

$$
\begin{aligned}
& \text { رسالة لمحمد زكريا الر ازي }
\end{aligned}
$$

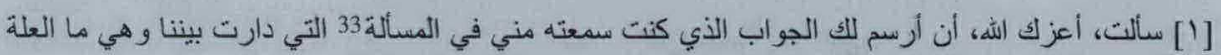

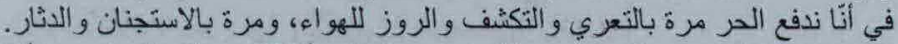

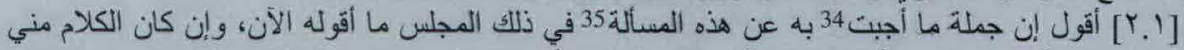

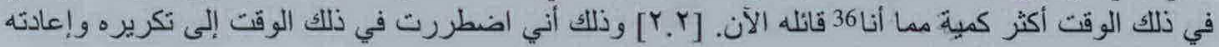

30. ("[W]alking for a long time in sunny places heats the whole skin of those who are naked excessively, and the head of those who are dressed ..."). Ed. C. G. Kühn, Galeni Opera omnia, 20 vols. (Leipzig: 1821-33), 7: 5 11. $12-15$.

31. The text in question is "Causes of Diseases," which formed part of a larger Alexandrian collection translated

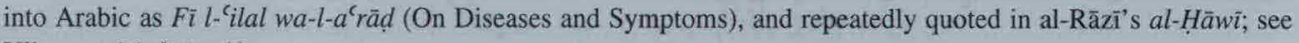
Ullmann, Medizin, 42.

32. Filius, Problemata Physica, 170-71, 172-73, respectively. Al-Rāzĩ deals with a similar question at $\$ 5.3-4$, below.

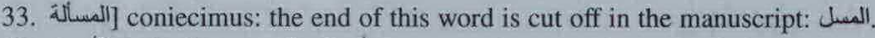

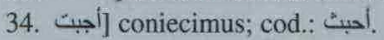

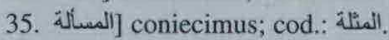

36. Lij our reconstruction of the word cut off at the end of the line. 


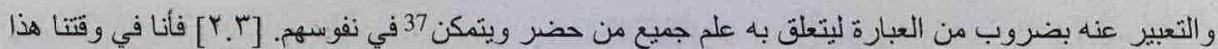

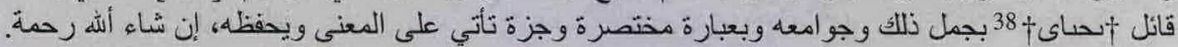

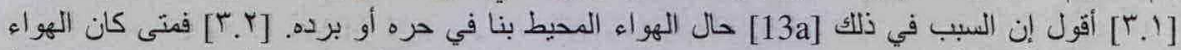

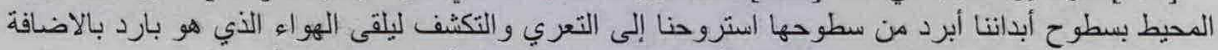

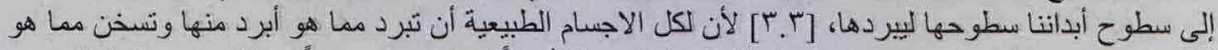

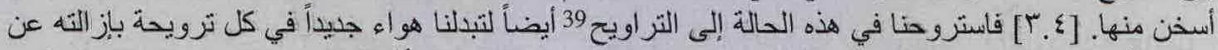

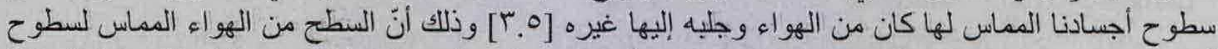

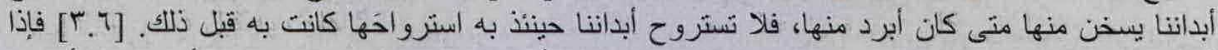

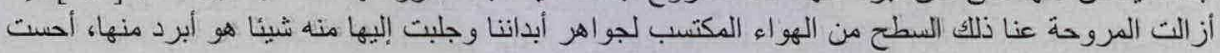

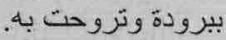

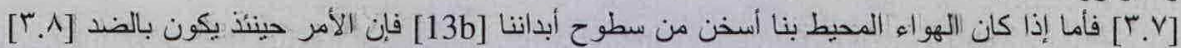

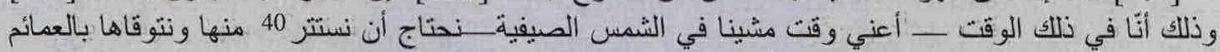

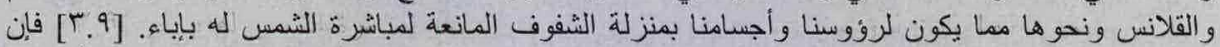

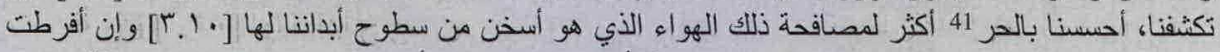

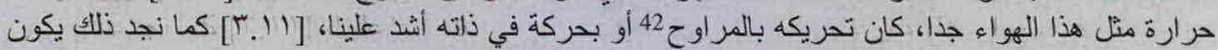

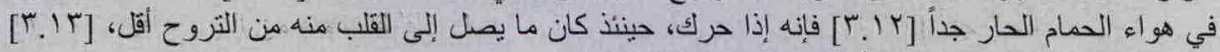

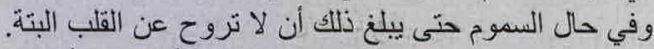

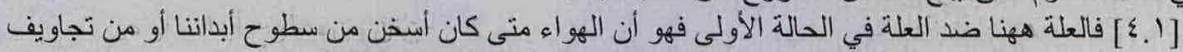

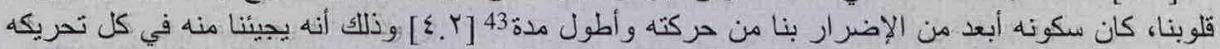

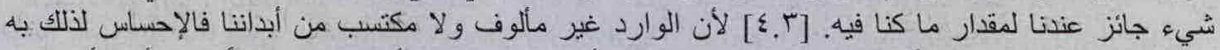

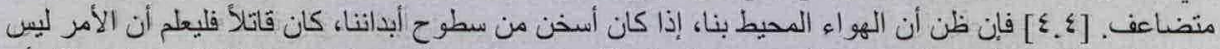

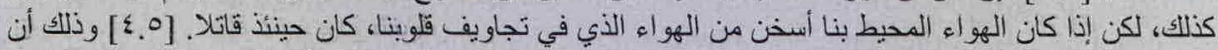

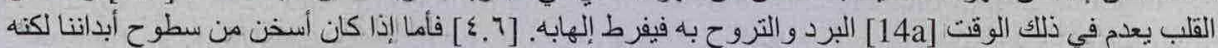

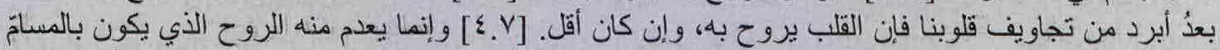

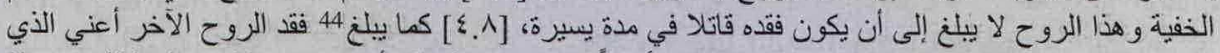

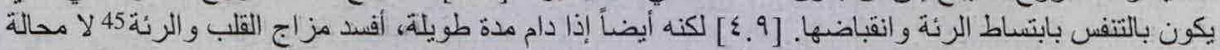

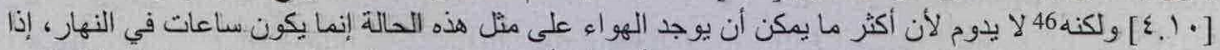

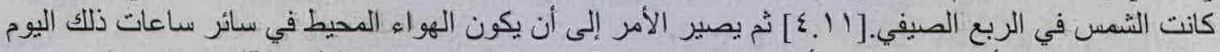

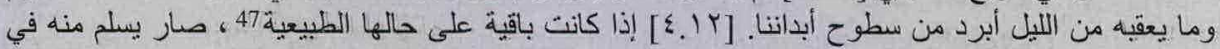

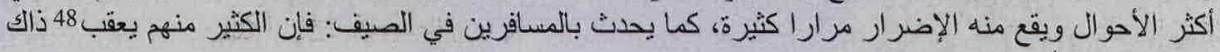

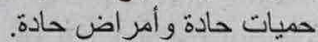

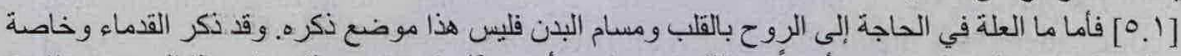

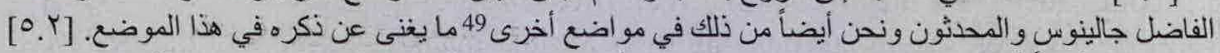

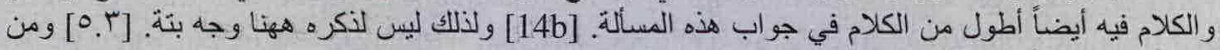

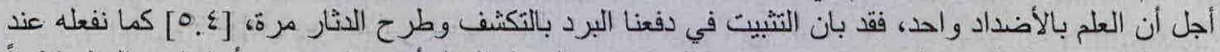

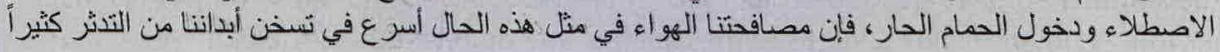

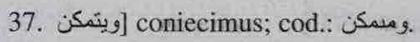

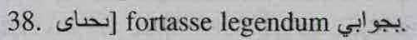

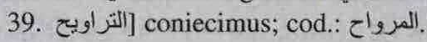

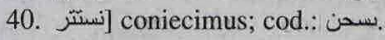

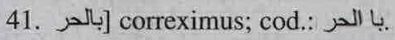

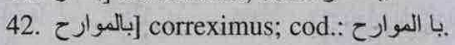

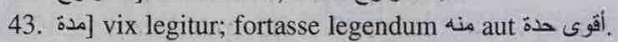

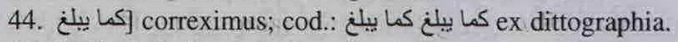

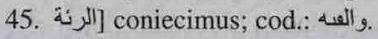

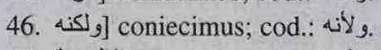

47. لطبيعية : الطبيعية.

48. تيعقب.

49. آخر : أخرى correximus; cod. 


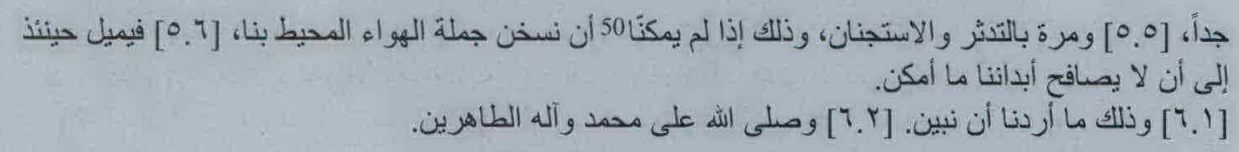

\section{Translation}

Epistle by Muhammad ibn Zakariyyä’ al-Rāzī

[1] You asked me-may God grant you strength - to write down for you the answer that you had heard me give to the question that we debated, namely, what the cause is for the fact that we sometimes expel heat by getting naked, taking off clothes, and seeking to be in the air, while sometimes we do this by covering and enveloping ourselves.

[2.1] I will now provide a summary of the answer that I gave to this question during this session (majlis), even if my discussion at the time was lengthier than what I am about to say here. [2.2] For at that time I had to repeat and restate it, and to express it in different ways, so that all those who were present would gain knowledge about it and retain it in their souls. [2.3] At the present time I am going to give my answer in the form of a summary and a digest, and in an abbreviated and concise form that provides and preserves the [overall] meaning, if God in His mercy wills it.

[3.1] I say that the reason for this is the air that surrounds us, insofar as it is hot or cold. [3.2] So when the air surrounding the surfaces of our bodies is colder than their surfaces, we seek refreshment by getting naked and taking off our clothes, in order that the air that is cold in comparison with the surfaces of our bodies meets with their surfaces, so as to cool them. [3.3] For all natural bodies are cooled by what is colder than they, and heated by what is hotter than they. [3.4] So in this condition we also seek refreshment by fanning, so that we can exchange new air with each instance of fanning through the fact that it [the new air] removes from the surface of our body the air that touches it [sc. the surface of our body] and draws something other than it [sc. the air that touches the surface] toward it [sc. the surface of our bodies]. [3.5] For the surface of the air touching the surfaces of our body is heated by it [sc. the surface of the body] when it [sc. the surface of the air] is colder than it [sc. the surface of the body]. Therefore our bodies are then not refreshed by it [the old air] in the way that they were before [sc. when the air was still cooler]. [3.6] So if the fan removes from us this surface of the air that surrounds the substance of our bodies and attracts to them some of it that is colder than they, they feel coldness and are refreshed by it.

[3.7] If, however, the air surrounding us is warmer than the surfaces of our bodies, then at that time the contrary is true. [3.8]. That is to say that, at that time, I mean, when we walk in the summer sun, we need to protect and guard ourselves against it with turbans, hats, and other things on our heads and our bodies such as the diaphanous fabrics that prevent the sun from having a direct effect through deflection.

[3.9] So if we undress, we feel the heat more because of the contact of the air that is warmer than the surfaces of our bodies with them [sc. the surfaces of our bodies]. [3.10] If air like this is quite excessively hot, then when it is moved by a fan or moves on its own, it causes us more difficulty. [3.11] We see this, for instance, happening with the air of a very hot bath: [3.12] if it is moved, then at that moment the air that reaches the heart is less refreshing. [3.13] In the case of hot wind (samüm), it even reaches the point that the heart is not refreshed by it at all.

[4.1] The cause here is the opposite of that in the first case, namely, that the air that is hotter than the surfaces of our bodies or the ventricles of our hearts causes less damage when it is still than when it moves, and does so [i.e., does not cause damage] for a longer period of time. [4.2] For every time it [the air] is moved, some of it that passes by us reaches us, to the extent that we 
are in it [the air, i.e., it affects us more, the longer we stay in the hot air]. [4.3] For when it [sc. this air] arrives, it is unfamiliar and has not previously been acquired by our bodies. Therefore, one senses it [sc. the hot air] twice as much. [4.4] If he thinks that when the air surrounding us is hotter than the surfaces of our bodies, it is deadly, then let him know that this is not the case. Rather, when the air surrounding us is hotter than the air that is in the ventricles of our hearts, then it is deadly. [4.5] For at that time the heart destroys the coolness and the refreshment that it [the coolness] brings, so that it is excessively burnt. [4.6] Yet, if it [the air] is warmer than the surfaces of our bodies, but still colder than the ventricles of our hearts, then the heart is refreshed by it [sc. the air], though less so. [4.7] Through it [sc. the air], only the pneuma that is in the hidden pores is destroyed. Losing this pneuma does not lead to death over a short period of time, [4.8] as losing the other pneuma does, namely, that which is produced through breathing when the lungs contract and expand [that is, the pneuma that moves from the lungs to the heart]. [4.9] But also, when it lasts for a long period of time, it inevitably corrupts the mixture of the heart and the lungs. [4.10] But it does not last [for a long time], because the longest that the air can exist in such a state is [a few] hours during the day, [and only] if the sun is in the summer quarter. [4.11] Then the situation changes so that the ambient air during the remaining hours of the day and the following night is colder than the surfaces of our bodies. [4.12] When they [sc. our bodies] remain in their natural state, one is safe from it [sc. death] in most cases, although through it damage is often caused, as it happens with those who travel in the summer: for many of them this is followed by acute fevers and acute diseases.

[5.1] This is not the place to discuss what the cause is why one needs the pneuma in the heart and the pores of the body. For the ancients discussed it, and especially the great Galen, and the moderns including me in other places, so that it is superfluous to do so here. [5.2] Moreover, to discuss it would take longer than my answer to this question. So, therefore, this is not the place [?] to mention it at all. [5.3] Because knowing opposites is one and the same thing [i.e., when one knows something, one also knows its opposite], it is clearly established that we sometimes ward off the cold by undressing and removing our coverings, [5.4] as, for instance, when we warm ourselves by a fire or enter a hot bath, for in this case our contact with the air warms our bodies much more quickly than if we were covered. [5.5] But at other times [we ward off the cold] by covering and enveloping ourselves, when we cannot heat all the air surrounding us; [5.6] for it [the cold air] tends to come into contact with our body as much as possible.

[6.1] This is what I wanted to show. [6.2] Peace be upon Muhammad and his righteous family.

\section{TEXT 2: "ON EATING WATERMELON"}

This treatise (maqāla) bears the title $F \bar{i}$ tanāwul al-tūt al-shāmī bi-'aqibi l-bitțīkh (On Eating Syrian Mulberries after Watermelons). ${ }^{51} \mathrm{Al}-\mathrm{R} a \bar{z} \mathbf{i}$ gave it a far longer title in his later work Manäfic al-aghdhiya wa-daf' madārrihä, which he explains is an attempt to correct some of the errors and lacunae of Galen's thoughts on the dangers of eating certain foods:

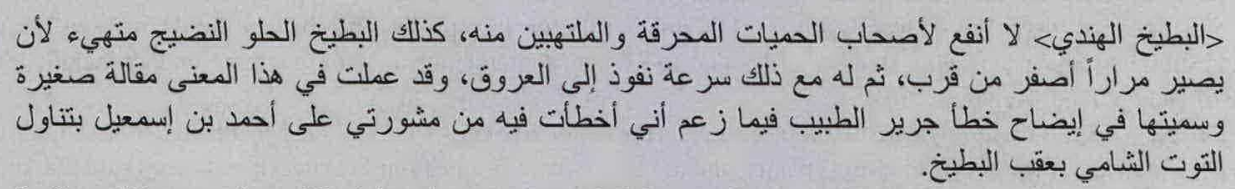

Indian Watermelon. Nothing is more useful for patients suffering from burning fevers and subsequent inflammation than this. Similarly, sweet ripe watermelon is apt to turn 
quickly into yellow bile, which also possesses the ability to penetrate quickly into the blood vessels. I wrote a short treatise on this subject and called it "Explanation of the Mistake Made by Jarir, the Physician, in That He Thought That I Made a Mistake When I Advised Ahmad ibn Isma'il to eat Mulberries after Watermelon." 52

The treatise addresses the health benefits of eating mulberries after watermelons, and more specifically how mulberries can counter the harmful effects of watermelons. Al-Rāzi opens the treatise with a paragraph $(\S 1)$ inveighing against the stupidity of other physicians in general and his unknown opponent in particular. This person criticized al-Rāzi for prescribing mulberries after watermelons in the concrete case of Ahmad ibn Ismā'il (849-907), the founder of the Samanid dynasty that ruled Transoxania and was largely based in Bukhārā. ${ }^{53}$ Then al-Rāzī briefly outlines the main features of the case: Ahmad was recovering from fever and doing well ( $\$ 2.1-2)$. Ahmad, we learn later $(\S 6)$, was very fond of watermelons and could not stop eating them. Al-Rāzī knew that eating watermelons would have a negative effect, by turning into bile; indeed, the sweeter the watermelon, the more harmful it was $(\S 2.3-7)$. Therefore he resolved to make the watermelon pass through the system quickly, before it could turn into harmful bile $(\$ 2.8-9)$.

Al-Rāzì explains that laxative drugs were not an option $(\S 3.1-2)$, but that mulberries were ideal ( $\$ 3.3-4)$. As flatulance was not an issue ( $\$ 3.5)$, al-Rāzì decided to resort to prescribing mulberries $(\S 4.1)$. The patient took al-Rāzì's advice, and the latter remained at his patient's bedside until the desired effect was achieved, namely, to calm the stomach and restore the appetite $(\$ 4.2-5)$.

In the next three paragraphs ( $\S 5-7)$, al-Rāzi counters putative objections to his course of action. First, he addresses the question of why he did not resort to oxymel (honey and vinegar boiled to a syrup), answering that it causes vomiting, weakens the patient, and spoils the appetite $(\S 5)$. Second, he deals with the objection that he should have simply ordered his patient not to eat watermelons at all; this, he explains, would have been impossible, since the patient would not have obeyed him, as he lacked medical knowledge $(\$ 6)$. Third, he counters the idea that he should simply have followed the advice of other physicians who prescribe various electuaries; these, he declares, are either ineffective or harmful (\$7.1-4). Al-Rāzì insists on the importance of experience here ( $(7.5)$, and adduces another case that confirms his views, in which he tested his theories on an unnamed patient ( $\$ 7.6-11)$. He argues in particular against Yahyā ibn Māsawayh and his work $F \bar{l}$ daf' madārr al-aghdhiya (On Repelling the Harm Inflicted by Foodstuffs) - though he uncritically cites this work in al-Ḥâwi and therefore evidently found it at one time to be of use. ${ }^{54} \mathrm{Ibn}$ Māsawayh's brief treatise is preserved in Berlin, Staatsbibliothek, MS Petermann 370, 3 (Ahlwardt 6408), and contains the following sentence, to which al-Rāzī takes violent exception:

52. Al-Rāzī, Manāfí al-aghdhiya wa-daf' madārrihā (Beirut: Dār Șādir, n.d.; repr. Cairo 1887), 46. In this work (p. 45) al-Rāzī makes the distinction between Syrian mulberries and sweet mulberries - being sour, the former reduce yellow bile and are therefore less dangerous to people suffering from fevers.

53. As noted (text at n. 8 above), Ibn Abī Ușaybía's title for this epistle confirms that the Ahmad ibn Ismāîl in question was a prince (amir). He also writes that al-Rāzì treated an emir in Khurāsān, a region that included the city of Bukhārā (ed. Najjār, 3: 20).

54. Al-Rāzī, al-Kitāb al-Hāwi fíl-tibb, 23 vols. (Hyderabad, 1955-70), 19: 372, specifically in a chapter on the poisonous qualities of certain drugs, plants, and animals, where he cites Ibn Māsawayh as having said that milk with honey is an antidote for the harmful properties of henbane, if preceded by vomiting cooked fig water along with various nuts, seeds, and plants. Nevertheless, within a few sentences of his introduction of Manäfi al-aghdhiya (p. 2) al-Rāzī also strongly condemns this work by Yaḥyā ibn Mãsawayh, accusing him of causing more harm than good with his writing. 


$$
\text { البطني: يؤكل بعده الكندر و الزنجبيل، و إن كان محرور اشرب بعده سكنجبين }
$$

Watermelons. Eat frankincense and ginger afterwards, and if he suffers from fever, he should drink oxymel afterwards. ${ }^{55}$

Al-Rāzī continues to lambast Ibn Māsawayh for providing dangerously inaccurate advice about watermelons ( $\$ 8.1-4)$. Finally, al-Rāzi states that his explanation is sufficient for anybody who has a smattering of medical knowledge. He claims that his opponent is even more ignorant than Ibn Māsawayh, which means that he is very stupid ( $\$ 8.5-7)$. Al-Rāzì ends by alleging that his opponent has been persuaded by his arguments and has vowed to give up medicine, which he should have done a long time ago ( $\$ 8.8-9)$. He concludes the treatise with a pious formula.

Ibn al-Bayțār, a leading pharmacologist of the thirteenth century, cites al-Rāzī's Manāi $i^{\varsigma}$ al-aghdhiya in his own work on drugs and foodstuffs, echoing much of the specific information found in our treatise below, namely, that watermelons, especially the sweet parts of watermelons far from the rind, turn quickly into bile and thus can cause tertian burning fevers. Likewise, Ibn al-Bayțār echoes al-Rāzī's criticism of Ibn Māsawayh's recommendations concerning the consumption of watermelon and the potential harm this might cause to those with kidney stones. So closely does his language resemble that of al-Rāzī's treatise that it seems likely that Ibn al-Baytạn had access to this treatise. Unlike al-Rāzī's treatise, however, Ibn al-Baytāar's work does counsel the use of oxymel after consuming watermelon. ${ }^{56}$

In al-Rāzì's treatise, the opponent, presumably a rival physician, remains anonymous, and there is little to suggest his identity. As noted above, in the bio-bibliographical literature and in al-Rāzī’s own titling, his name is given as Jarīr, "the physician." Unfortunately, we were unable to discover any more information about him.

The text is polemical in tone, with al-Rāzĩ attacking those who oppose his opinion about the potential harm of eating watermelon and the possible benefits of following the watermelon with mulberries as ignorant, stupid time-wasters. In particular he defends his treatment of the ruler of a powerful dynasty. As in the first epistle, the setting for this dispute appears to be the court: al-Rāzī's opponent criticized him publicly and with this treatise, al-Rāzì sets the record straight. In his Risāla ilā ba'd talämidhihì (Epistle to One of His Students), al-Rāzī's first piece of advice to the aspiring doctor concerns the difficulty of treating members of the court, since both doctors and their royal patients are accustomed to giving and not receiving orders (indeed, he addresses this problem in this epistle, stating that his patient would probably not have obeyed him if he had been commanded to cease eating watermelon). ${ }^{57} \mathrm{We}$ also know about rivalries between physicians in these high-stakes positions. One such rivalry allegedly cost the physician and translator Hunayn ibn Ishāq his position as court physician and even his freedom. ${ }^{58} \mathrm{Al}-\mathrm{R} a \overline{z i}$ 's polemics were not limited to the court setting; he also inveighed against women and charlatans with great vigor. ${ }^{59}$ Generally, as in the treatise below, al-Rāzĩ demonstrates what he considers his superior medical knowledge and makes

55. Fol. 144b 1. 14; Ibn Abĩ 'Ușaybía (ed. Müller, 1: 183) discusses Ibn Māsawayh and his work on food, as described below.

56. Ibn al-Bayțār, al-Jāmi ' li-mufradāt al-adwiya wa-l-aghdhiya, 4 vols. in 2 (Baghdad: Maktabat al-Muthannā, [1966]; repr. Bulaq 1291 $h$ [1875]), 1: 99-100.

57. Ed. 'A. L. M. al-Aabd, Akhlāq al-tabīb: Risāla li-Abì Bakr Muhammad ibn Zakariyyā’ al-Rāzī ilā ba'd talāmidhihï (Cairo: Maktabat Dār al-Turāth, 1977), 17-19.

58. M. Cooperson, "The Purported Autobiography of Hunayn ibn Ishāa," Edebiyât 7.2 (1996): 235-49.

59. P. E. Pormann, "The Physician and the Other: Images of the Charlatan in Medieval Islam," Bulletin of the History of Medicine 79 (2005): 189-227; repr. in Islamic Medical and Scientific Tradition: Critical Concepts in Islamic Studies, ed. P. E. Pormann, 4 vols. (Abingdon, UK: Routledge, 2011), 2: 203-39. 
short shrift of his competition, and we can only speculate whether he is animated by a desire to promote good medical practice or to maintain his reputation as a physician, with all the attendant benefits that this brings.

Here al-Rāzī's topic of discussion is clearly influenced by Galen's description of mulberries in his De alimentorum facultatibus. ${ }^{60}$ After a lengthy discussion of different terms for mulberries, Galen insists that knowing their medical effects is more important than a familiarity with obscure terminology. Galen warns that mulberries, like melons, tend to pass quickly through the digestive tract, but if they are made to linger (having been eaten after another food, which, perhaps, has temporarily obstructed the digestive tract), they are corrupted. However, unlike melons, mulberries are not bad for the stomach, and perhaps have a stronger laxative effect. Al-Rāzī develops what is suggested by Galen, writing that mulberries' laxative effect, if they are eaten after watermelons, can prevent any possible harm caused by the melons themselves.

The fears concerning the eating of fruits that produce certain harmful matters in the body are found in many other ancient and medieval texts containing medical discussions. For example, in Athenaeus's Deipnosophistae III 19-20, diners discuss the relative merits of eating different types of apples ("apples that are green and not yet ripe are full of bad juice, and are bad for the stomach; but are apt to rise to the surface, and also to engender bile; and they give rise to diseases, and produce sensations of shuddering"'), and their tendency to aid or harm digestion or to produce favorable or harmful juices in the body. ${ }^{61}$ Similarly, Ibn Abī Șādiq's eleventh-century commentary on Hippocratic aphorism iii.9, which states that diseases are most acute in the autumn, attributes this to the fact that the eating of fresh fruits in the summer can build bad juices (kaymūsāt) in the body, ${ }^{62}$ and Ibn al-Quff's thirteenthcentury commentary on aphorism iii.21 (concerning illness common in the summertime) specifically discusses the dangers of consuming watermelon, stating that along with other foods commonly consumed in the summer, such as peaches, watermelons are quick to corrupt in the stomach. ${ }^{63}$

\section{Edition}

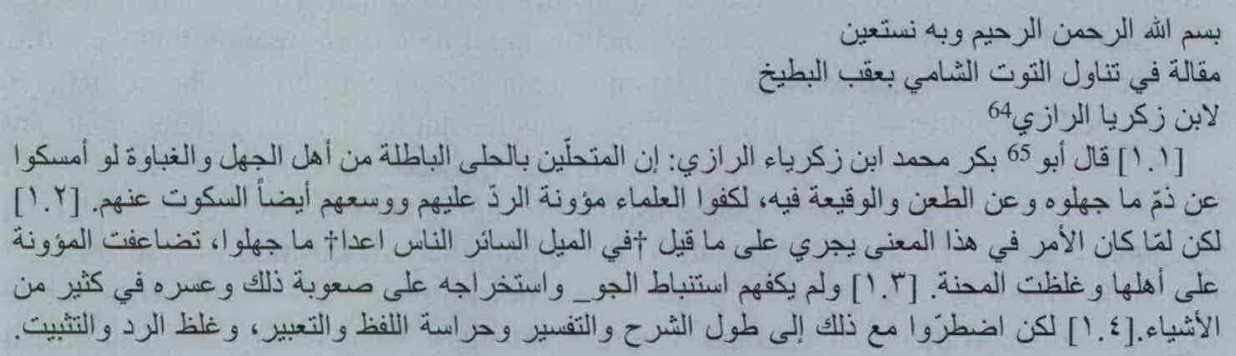

60. Galen, De alimentorum facultatibus, bk. 2, ch. 11, ed. G. Helmreich (in Galen, De sanitate tuenda, etc. [Leipzig and Berlin: B. G. Teubner, 1923]), 283-84; tr. O. Powell, On the Properties of Foodstuffs (New York: Cambridge Univ. Press, 2002), 81-83 (modified).

61. Athenaeus, Deipnosophistae, ed. G. Kaibel, 3 vols. (Leipzig: B. G. Teubner, 1887-1890), 3: 20; tr. Ch. D. Yonge, The Deipnosophists, or, Banquet of the Learned of Athenaeus, 3 vols. (London: H. G. Bohn, 1854), 1: 135 (modified).

62. Dublin, Chester Beatty MS Ar. 3802, fols. 62a-b; Istanbul, Beyazid Devlet Kütüphanesi, MS Veliyeddin Efendi 2508, fol. 27b (DOI: 10.3927/51932105):

القوى تخكلل في الصيف وتفسد الأخلاط في الخريف بسبب تثاول الفو اكه الرديبة الفجة.

63. Istanbul, Yeni Camii, MS Yeni Camii 919, fol. 158a (DOI 10.3927/52132051).

64. الراز ازازي إزئ correximus: cod.

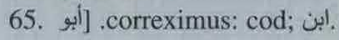


[1.0] ومن أجل ذلك اضطررنا إلى مقابلة الطاعن علينا في مشورتنا على أحمد بن إسمعيل بتناول شيء من بن

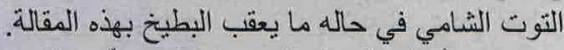

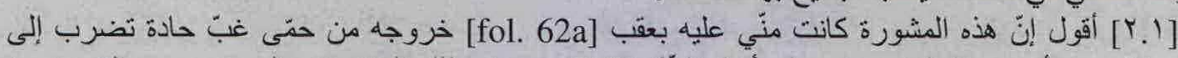

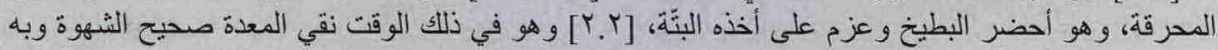

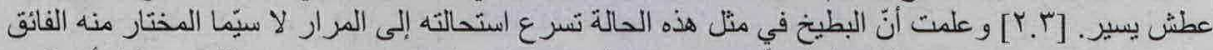

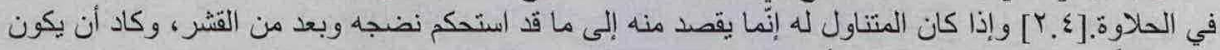

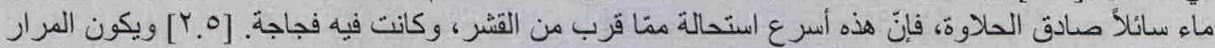

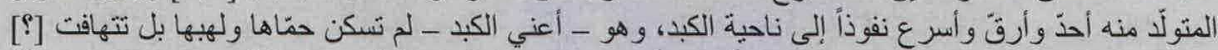

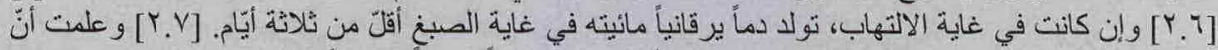

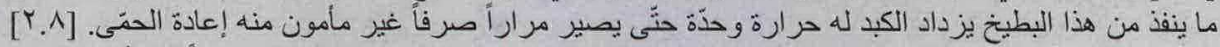

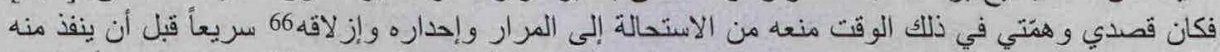

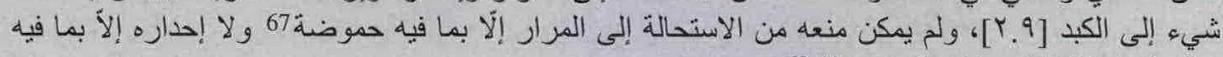

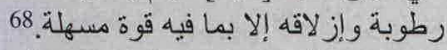

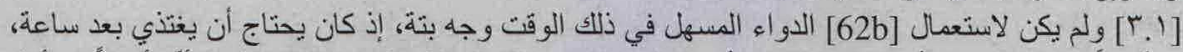

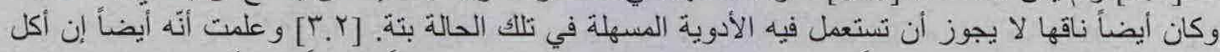

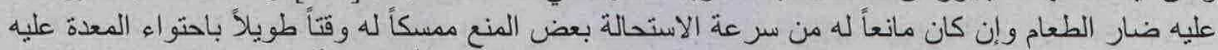

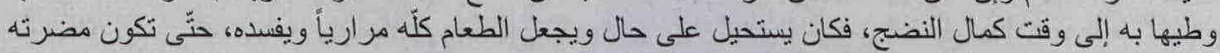

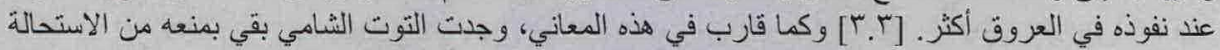

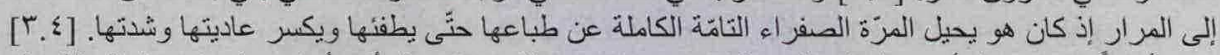

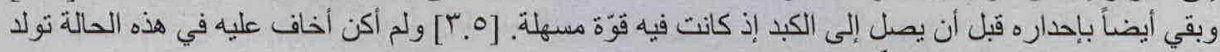

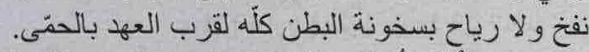

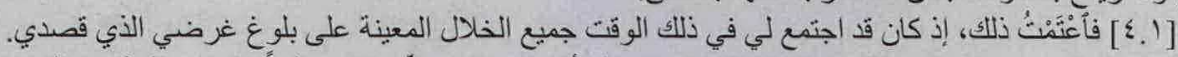

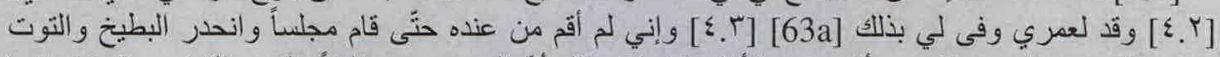

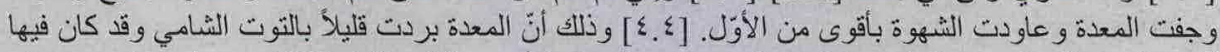

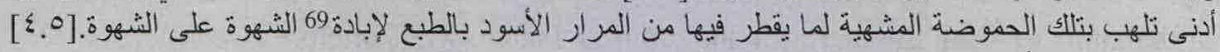

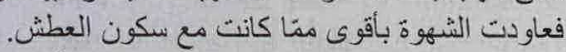

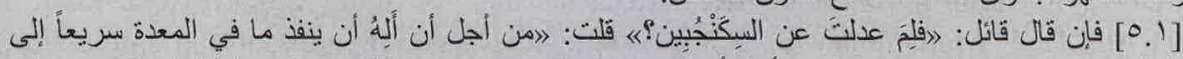

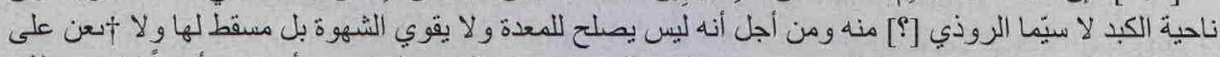

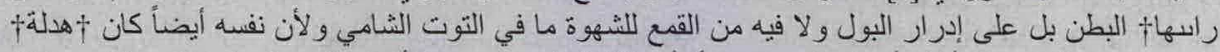

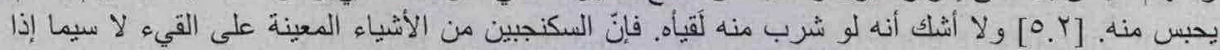

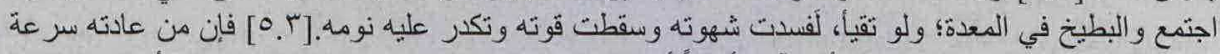

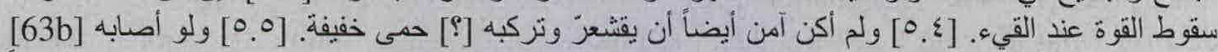

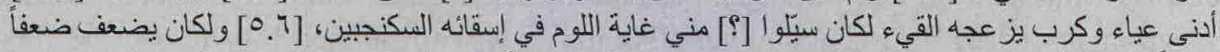

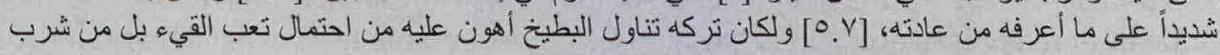

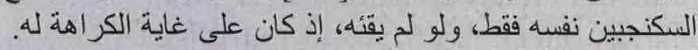

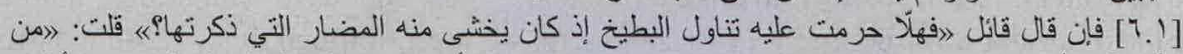

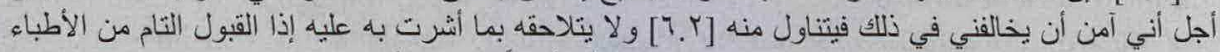

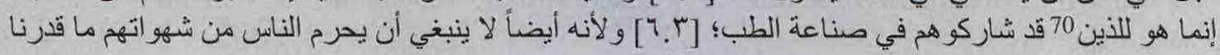

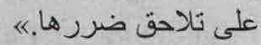

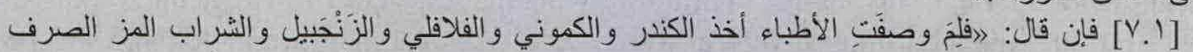

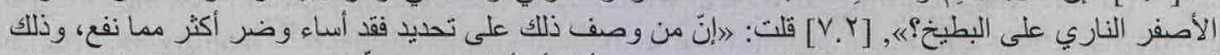

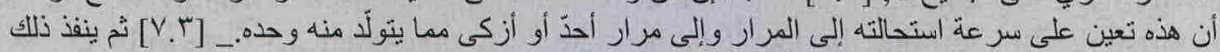

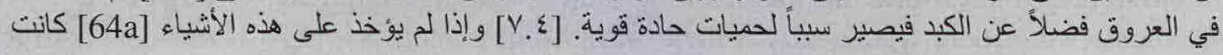

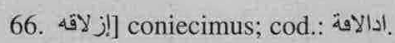

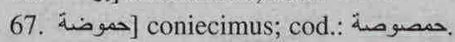

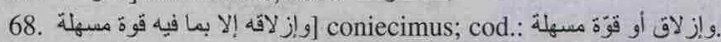

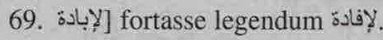

70. الأذين : الإد. 


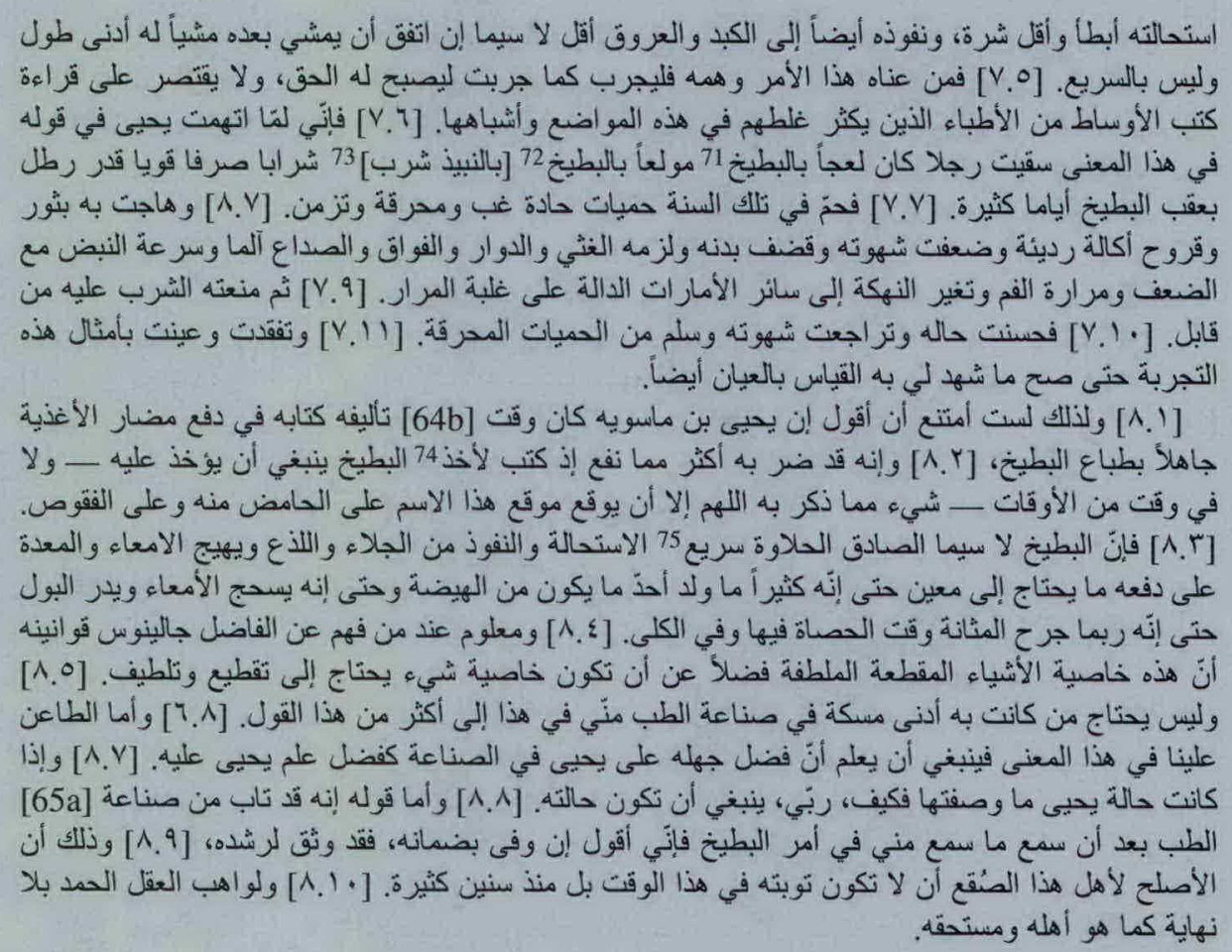

\section{Translation}

In the name of God, the merciful and compassionate, whose help we seek

A treatise on eating Syrian mulberries after watermelons, by Ibn Zakariyyā’ al-Rāzī

[1.1] Abū Bakr Muhammad ibn Zakariyyā' al-Rāzī said: If ignorant and stupid people who adorn themselves with useless frippery refrained from criticizing, slandering, and vilifying what they do not understand, they would spare intelligent people the trouble of refuting them, and they [the intelligent people] could just pass them [the ignorant ones] over in silence. [1.2] But since the matter in this case is as we have said, namely, that they tend to despise what they do not know [?], the intelligent people's trouble is doubled and their hardship increased. [1.3] It is not enough that they have to lose their breath, because this is so difficult in many instances, [1.4] but they also must provide long explanations and commentaries, and protect the text [from misinterpretation]; it is arduous to refute [these ignorant people] and to establish [the truth]. [1.5] Therefore, we must, through this treatise, confront the person who criticized us for having advised Ahmad ibn Isma'il to consume mulberries after watermelons.

[2.1] I am referring to my advice to him following his recovery from an acute tertian fever that was turning into a burning [fever], at which point he got some watermelon and was positively resolved to eat it. [2.2] At that time he had an empty stomach, a healthy appetite, and little thirst. [2.3] I knew that for people in this state, watermelon quickly turns into bile, especially those [watermelons] chosen for their exceptional sweetness. [2.4] If someone eating it

71. بالبطيخ ] بالبطيخ : correximus; cod.

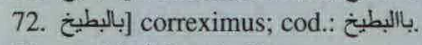

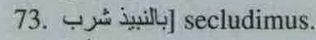

74. لاحاحد: الأخ coniecimus; cod.

75. سر عة التريع. coniecit Ullmann; cod. 
chooses only the part that is thoroughly ripened and far from the rind, so that it is almost all liquid flowing in pure sweetness, then this changes more quickly than that which is close to the rind and slightly unripe. [2.5] The bile generated by this [the latter] is sharper and thinner, and penetrates more quickly toward the liver; its - that is, the liver's-burning fever does not subside but follows one after another [?]. [2.6] In states of extreme high temperature [the liver] generates jaundiced blood, which is extremely deeply dyed for less than three days. [2.7] I had come to know that when this [type of] watermelon reaches [the liver] it causes it to increase in warmth and acidity, so that it [sc. the watermelon] turns into pure bile, which could potentially lead to the return of the fever. [2.8] It was, therefore, my aim and intention at that time to prevent it from turning into bile, and to make it slip down quickly, before any of it could reach the liver. [2.9] It can, however, only be prevented from turning into bile by something acrid, only be made to go down by something moist, and only be made to slip out by something having a purging faculty.

[3.1] The use of laxative drugs at that time was by no means an option, since he needed nourishment soon, and was also recovering, so that one ought not to use any laxative drugs at all, given his condition. [3.2] I also knew that if he ate harmful food after it [sc. a laxative drug], then even if it [the laxative drug] would somehow prevent it [the food] from changing quickly and would hold it for a long time by having the stomach contain and envelop it [the food] until it were fully digested, it [the laxative] would in any case change [into bile], and thereby render the food bilious and corrupt. Therefore, the damage that it [the food turned bile] causes when penetrating into the blood vessels would be even greater.

[3.3] In this context, I saw that mulberries continue to prevent it [food] from changing into bile, because they [even] change absolutely perfect yellow bile from its natural state so that they extinguish it and remove its harmful and intense effect. [3.4] They also continue to make it go down before it reaches the liver, since they have a purgative power. [3.5] Given his condition, I was not afraid that flatulence and wind would be generated by the whole belly being hot because the fever was recent.

[4.1] Therefore, I chose this [sc. administering mulberry], because at that time all the requirements necessary to fulfil the aim that I set myself had come together. [4.2] By my life, he kept his promise to me that he would do this. [4.3] I did not leave his bedside until he passed stool, the watermelon and berries came down, the stomach became dry, and his appetite returned stronger than before. [4.4] For the stomach was cooled a little by the mulberries, and there was the slightest burning in it caused by this acidity, stimulating to the appetite, because of the black bile that naturally flows into it to annihilate successive bouts of appetite. [4.5] Thus the appetite returned stronger than before, as the thirst was quenched.

[5.1] So if somebody were to ask, "Why did you refrain from using oxymel?" I would say, "Because I am afraid that what is in the stomach quickly penetrates to the region of the liver, especially the kind [of oxymel] made with roses. Moreover it [sc. oxymel] is not appropriate for the stomach, and it does not strengthen the appetite, but rather weakens it. Neither does it help to purge the belly [?], but rather has a diuretic effect, nor does it suppress the appetite as mulberries do, and because it itself is ... [?] that one ought to avoid." [5.2] I do not doubt that if he had drunk it, he would have vomited it, for oxymel is something that aids vomiting, especially if it mixes with watermelon in the stomach. If he had vomited, his appetite would have been ruined, his strength would have failed, and his sleep would have been troubled. [5.3] For when someone vomits, his strength is usually weakened quickly. [5.4] Moreover, I could not be certain that he would not shiver and be attacked [?] by a light fever. [5.5] For if even the slightest exhaustion and worry had befallen him and stimulated his vomiting, they would have poured blame on me to the utmost for having given him oxymel to drink. [5.6] He would have grown much weaker, as it [the oxymel] normally has this effect, according to 
my knowledge. [5.7] It would have been easier for him to avoid eating watermelons than to bear the exhaustion caused by vomiting - easier even than just to drink oxymel on its own, if it did not cause vomiting - because he really hated it [sc. oxymel].

[6.1] So when someone asks, "Why did you not forbid him to eat watermelons, since one is afraid of the damage that you mentioned?" I retort, "Because I am sure that he would have opposed me and eaten it anyway, [6.2] and would not have corrected its effect by what I had indicated to him. One only accepts completely what physicians order if one belongs to them [and is trained] in the art of medicine; [6.3] and also because one ought not to forbid people from what they desire as long as one can correct the damage."

[7.1] And if he says, "Why did the doctors prescribe taking frankincense, cumin [electuaries], ${ }^{76}$ pepper [electuaries], ginger, and sour yellow unmixed fiery wine after eating watermelons?" [7.2] we retort, "Whoever prescribed this categorically acted wrongly, and did more harm than good, because these things help quickly turn watermelon into bile, and into sharper or purer bile than what would be generated by it on its own. [7.3] Then this [bile] penetrates the blood vessels, not to mention the liver, and can thus cause strong acute fevers." [7.4] If one does not take these things, [the watermelon] turns [into bile] more slowly and with fewer bad consequences, and it also penetrates the liver and the blood vessels to a lesser extent, especially if he happens to walk afterwards a very short distance, and not quickly. [7.5] If someone is interested in this and concerned by it, then he should experiment as I have, so that the truth might dawn on him. He should not limit himself to reading the books of mediocre physicians who commit many errors as regards this subject. [7.6] Since I had reservations about Yahyā [ibn Māsawayh] and what he said about this, I gave a man who ardently desired watermelon pure strong wine to drink in the amount of one ritl, after [having eaten] watermelon for many days. [7.7] Then he was affected during that year by many acute burning tertian fevers, which became chronic. [7.8] This caused pustules and malignant corrosive ulcers, his appetite weakened, his body grew emaciated, he constantly suffered from nausea, dizziness, hiccups, and headache, and rapid pulse with weakness, bitterness of mouth, a change in the smell of his breath, and all the other symptoms that indicate the domination of bile. [7.9] Then, [in the next year], I forbade him to drink [sc. wine] as before. [7.10] His state improved, his appetite returned, and he fully recovered from the burning fevers. [7.11] I investigated and saw myself things similar to this experience, so that the testimony given to me by reason was proven correct by my own observation.

[8.1] Therefore I do not refrain from saying that Yahyā ibn Māsawayh was ignorant of the nature of watermelons when he wrote his book "On Repelling the Harm Inflicted by Foodstuffs." [8.2] With it, he did more harm than good, ${ }^{77}$ since he wrote on the subject of watermelons that one ought to take after it - and not just sometimes - something that he mentioned, except that the term [watermelon] was applied to the sour [variety] of it and to large cucumbers (fuquss). [8.3] For watermelon, especially the truly sweet kind, is quick to transform and penetrate owing to its cleansing and stinging quality, and it stimulates the intestines and the stomach to push what requires assistance, ${ }^{78}$ so that it often generates the sharpest possible form of diarrhoea ( $h a y d a$ ), abrades the intestines, stimulates urination, and may even harm the bladder when a stone is in it or in the kidneys. [8.4] Those who understand the principles set out by the great Galen know that this is a specific characteristic of

76. M. Ullmann, ed., Wörterbuch der klassischen arabischen Sprache (Wiesbaden: Harrassowitz, 1955-2009), 1: $365 \mathrm{~b} 37-366 \mathrm{a} 2$.

77. As noted (n. 36 above), al-Rāzĩ repeats this accusation in the opening sentences of his Manäfí al-aghdhiya. 78. I.e., it helps to push down food that cannot come out on its own. 
cutting and thinning substances, not to mention that it is a specific characteristic of anything that needs to be cut and thinned. [8.5] So anyone with the slightest grasp of the art of medicine requires no further explanation from me here. [8.6] The person who criticizes us on this subject should know that he exceeds Yahyā [ibn Māsawayh] in ignorance as much as Yahyā exceeds him in knowledge. [8.7] And if Yahyā's ignorance is as I described it, then, oh Lord, how very ignorant must he be? [8.8] When he says that he repented of practicing medicine after he heard what I said about watermelons, I retort that if he keeps his pledge, then one can have confidence, because he is rightly guided [in doing so]. [8.9] For it would have been best for the inhabitants of this region, if he had repented not just at this time, but many years ago. [8.10] Praise without end be to him who giveth intelligence, as is right and meet.

\section{CONCLUSIONS}

Both epistles edited and translated here for the first time arose out of the competitive court culture that dominated much of Abbasid society. In both epistles al-Rāzi mentions that the topic of discussion originally arose during a majlis, which could refer to a courtly setting of what essentially amounted to state-sponsored debate, or to a less formal social gathering in which learned people discussed intellectual matters, perhaps over a meal or a beverage (i.e., a symposium). In the first epistle al-Rāzī summarizes his arguments against an unknown opponent. The topic is one of natural history and related to the $M \bar{a} b \bar{a} l$ or problem literature that goes back to Problémata physiká attributed to Aristotle. The second epistle arose from a concrete situation, namely, critique of al-Rāzĩ for prescribing mulberries after watermelon in the case of Ahmad ibn Ismā̄il, the founder of the Samanid dynasty. Again, we are in a court setting and competing physicians vie for the attention of the political elite.

This competitive court culture did not affect only al-Rāzī's career. In the autobiography of Ḥunayn ibn Ishāâq as recorded in Ibn Abī Ușaybía, we read about an incident, alluded to above, in which Hunayn's Christian rival, a fellow physician, tricked him into spitting on an icon in front of the caliph, who quickly jailed him for this transgression. Only when the caliph required medical attention and other doctors were unable to offer a cure did he consult Hunayn, after having been thus instructed in a dream. Hunayn effected the cure and not only regained his old position but curried even greater favor with the caliph. Although the historicity and authenticity of this account remain disputed, it illustrates that rivals at court could go to great lengths to eliminate the competition. ${ }^{79}$ Likewise, al-Kindī reportedly lost his library in a court intrigue, and only had it restored when the Banū Mūsā botched an engineering job and were at the mercy of someone who, despite an enmity between al-Kindi and himself, insisted that they make amends. ${ }^{80}$

One might ask whether the questions discussed in these two epistles were of any practical relevance. After all, the question of why one sometimes undresses to get warm would appear rather academic. Here again, a parallel case is illuminating. There is a wonderful exchange of letters between two physicians, the Christian Ibn Buttān from Baghdad and the Muslim Ibn Rị̣wān from Cairo, who argued about whether "the chicken has a warmer nature than a young bird." ${ }^{81}$ This also appears to be a problem of natural history that is of little practical

79. Cooperson, "Purported Autobiography."

80. P. Adamson and P. E. Pormann, eds. and trs., The Philosophical Works of al-Kindi (Karachi: Oxford Univ. Press, 2012), 1xvii-lxviii.

81. See M. Meyerhof and J. Schacht, The Medico-Philosophical Controversy between Ibn Butlan of Baghdad and Ibn Ridwan of Cairo: A Contribution to the History of Greek Learning among the Arabs (Cairo: Egyptian Univ., 1937). 
implication, but it stirred up a great controversy. In the course of their exchange of letters, they accuse each other of being quacks, not true physicians. The very credibility of the medical practitioner seems to depend on his ability to converse about topics of natural history. ${ }^{82}$

The broader topic of the second epistle, what and how to eat, is also of great relevance to court life. Here we can quote an anecdote from Ibn Abi 'Ușaybi'a's biographical entry on Ibn Māsawayh, whom al-Rāzī attacks in his epistle. Although this physician wrote medical treatises on a range of topics, he had a special interest in the order in which foodstuffs are consumed:

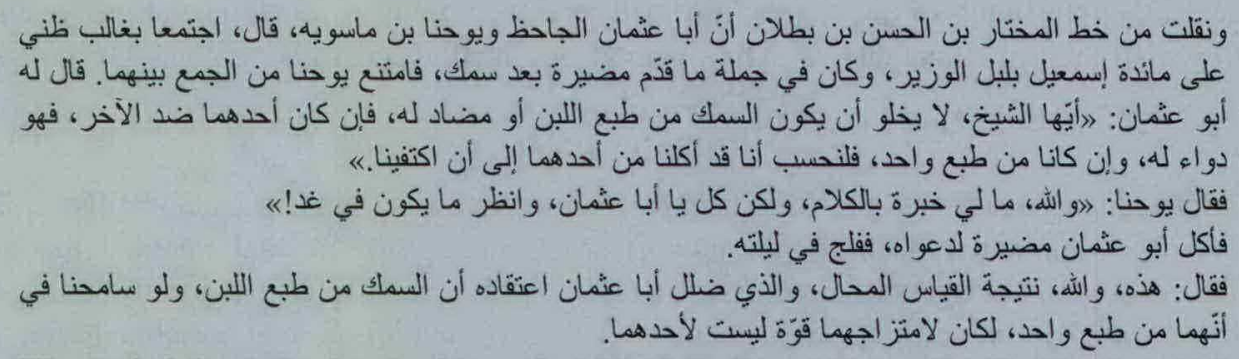

We copied from the handwriting of al-Mukhtār ibn al-Ḥasan ibn Buțlān that Abū 'Uthmān al-Jāhị and Yuhannā ibn Māsawayh, he said, were together (almost certainly in my opinion) at the table of Isma il Bulbul, the vizier. Among the foods presented were fish followed by madīra [soured milk stew], and Yuhannã refrained from mixing the two. Abū 'Uthmān said to him, "Sir, fish must inevitably be either of the nature of milk or its opposite. If one is the opposite of the other, then it will be a remedy for it, but if they are of the same nature, then we must conclude that we may eat either one of them until we are satisfied." "By God," answered Yuhannā, "I have no knowledge of rhetorical debate, but eat, Abū 'Uthmān, and see what happens tomorrow!" Abū 'Uthmān ate because of what he claimed, and was struck with hemiplegia that night. "This," [Yuhannā] said, "is the result of false reasoning. Abū 'Uthmān was misled to believe that fish is of the nature of milk. If we conceded that they are both of the same nature, then they would possess a faculty when mixed together not found in one of them alone." 83

This anecdote features the famous father of Arabic prose, Abū 'Uthmān al-Jāhịiz (d. 868), copied from the handwriting of Ibn Butlān, a man known for both his medical skill and his literary talents (and the adversary of Ibn Ridwān in the exchange of letters discussed above). In its blending of the rhetorical and the medical, it demonstrates the complex relationship of rhetoric and speech to food and the body, as well as the competitive debate atmosphere that surrounded the study of medicine. Although rhetoric and debate were pervasive in all fields of learning, in medicine they inevitably implied a balance between erudite book-learning and the demands of the physical body. One may engage in sophistry on any topic under the sun, but the results of such rhetorical activity could have very real and dire consequences when they influenced medical treatments.

Al-Rāzi's competitive tone has broader roots in rhetorical practices close to the ancient Greek sources from which he draws in his medical practices. These same ancient Greek sources strongly influence the epistolary tradition in which al-Rāzì is participating. In particular, his epistle on eating watermelons before mulberries, the more belligerent one, displays 
characteristics of rhetorical debating styles and even of vaunting. ${ }^{84}$ Despite his rhetorical flourishes, however, al-Rāzì seems earnest in his desire not only to advance his career but to share his medical knowledge, which he claims he tested empirically and bore witness to "with [his] own eyes." 85 The risāla genre provides the perfect setting for the dissemination of original medical theories like those expressed in these treatises.

84. See, e.g., G. Anderson, The Second Sophistic: A Cultural Phenomenon in the Roman Empire (London: Routledge, 1993); G. J. H. van Gelder, The Bad and the Ugly: Attitudes towards Invective Poetry (Hijā') in Classical Arabic Literature (Leiden: E. J. Brill, 1988).

85. On al-Rāzī's views of the use of medical experience, see P. E. Pormann, "Medical Methodology and Hospital Practice: The Case of Tenth-Century Baghdad," in In the Age of al-Fārābĩ: Arabic Philosophy in the Fourth/ Tenth Century, ed. P. Adamson (London: Warburg Institute, 2008), 95-118; repr. in Islamic Medical and Scientific Tradition, ed. Pormann, 2: 179-206. 
Copyright of Journal of the American Oriental Society is the property of American Oriental Society and its content may not be copied or emailed to multiple sites or posted to a listserv without the copyright holder's express written permission. However, users may print, download, or email articles for individual use. 